\title{
The value experience of the emotional immersion in games
}

\section{Jan Franciszek Jacko}

Jagiellonian University | 379@wp.eu | ORCID 0000-0002-5654-1039

\begin{abstract}
The study presents a phenomenological analysis of the value experience in the emotional immersion in games. The text shows two possible variants of this experience: emotional illusion and delusion. In the emotional illusion, players emotionally distance themselves from their hierarchy of values to enjoy the game. With emotional delusion, emotions motivate players to deny their hierarchy of values. The study explains this distinction in the context of certain theories of rational action.
\end{abstract}

Keywords: immersion in games, emotional immersion, rational player, ethics, impression management 



\section{Introduction}

Immersion in games takes place when a player realistically experiences the reality represented in them (Brown \& Cairns, 2004; Jennett, Cox, Cairns, Dhoparee, Epps, Tijs, Walton, 2008; Qin, Rau \& Salvendy, 2010; Sweetser \& Wyeth, 2005). Sensory (spatial) immersion is the impression of "real" presence and emotional immersion consists of the emotional experience of this reality (Baños, Botella, Alcañiz, Liaño, Guerrero \& Rey, 2004; Jennett et al., 2008). For example, emotional immersion takes place in narrative games, when "the user feels emotionally aroused and absorbed by the narrative content of the story. Different from spatial immersion, emotional immersion does not necessarily allow users to feel the 'bodily presence' into the scene, but allows them to be cognitively identified and emotionally empathised with one of the characters of the story or avatars in the game world" (Zhang, Perkis, \& Arndt, 2017).

Prior ethical studies of digital games have often focused on the harmful effects of immersion (Anderson \& Dill, 2000; Bushman \& Anderson, 2002; Grüsser, Thalemann, \& Griffiths, 2007). However, there has been a shift of focus from consequences of immersion towards its subjective experience (Komulainen, Takatalo, Lehtonen, \& Nyman, 2008; Nacke, Drachen, Kuikkaniemi, Niesenhaus, Korhonen, Hoogen \& Kort, 2009). Ludological studies have investigated the modifications of this experience in gameplay, such as the sense of presence (Slater, 2002), experience of flow (Cowley, Charles, Black, \& Hickey, 2008), peculiar perception of time (Jennett et al., 2008; Qin, Rau \& Salvendy, 2010), or emotional attachment to the play and detachment from reality (Sweetser \& Wyeth, 2005; Jennett et al., 2008; Qin et al., 2010). Although affective ludology has investigated the experience of emotional immersion (Mathiak, Weber, 2006; Nacke, 2009), researchers have noticed that its concept remains unclear in literature and a phenomenological analysis is required to clarify the idea of emotional immersion (Brown, Cairns, 2004, p. 1297; Lindley, Nacke, \& Sennersten, 2008; Ravaja et al., 2009).

This article is a phenomenological study of emotional immersion in gameplay. The analyses contribute to the state of research by specifying the intentional structure of emotions in the experience of immersion and by showing how these emotions relate to values. We assume that 
this type of immersion contains the experience of values because in the emotional involvement in the game the player emotionally experiences the goals, rules, and the course of his/her victory in the game as values (worth realising, respecting, following). The method of phenomenological analysis determines two variants of this experience - the emotional illusion of games and the emotional delusion of games. By 'emotional illusion' we mean the player's emotional enrolment to the values of the game and distance to his/her hierarchy of values. We show how the illusion can transform into the emotional delusion of games when the emotions of the agent provoke him/her to deny his/her hierarchy of values. The objective of the study is to specify and explain these two modes of the value experience.

The distinction between emotional illusions and delusions is implicit in some theories of emotional immersion. Examples include the concepts of flow and total immersion (Csíkszentmihályi, 1975, 1990), degrees of immersion (Dansky, 2006), engagement, engrossment, and total immersion (Brown \& Cairns, 2004; Nacke \& Lindley, 2008; Jennett et al., 2008), organic and interactive emotions (Hochschild, 1979), or cognitional aspects of emotional immersion (Ortony et al., 1990). This study makes that distinction explicit, presents the phenomenological analysis of the two modes of emotional immersion and explains their distinction in the context of some conceptions of rational action.

\section{Definitions and assumptions}

The text does not investigate psychological discussions about the difference between emotions, feelings, and similar experiences (for example, moods, affects, passions, sentiments). We follow the conception of emotions by Max Scheler. According to him, emotions are immediate experiences of values or anti-values. These are correlates of emotions. Positive values are not only emotionally given as that which entices us but also as that which ought to be. Analogously, negative values emotionally present themselves as that which ought not to be. Scheler maintains that emotions present some hierarchy of values (people emotionally experience that some values are more important than some other values). 
Besides emotions in the above sense, there can be non-intentional feelings and similar phenomena that do not relate to any values. There are also non-emotional acts that relate to values, such as decisional value preferences (Davis \& Steinbock, 2016; Mandryk, Inkpen, 2004; Ravaja, et al. 2005, 2009).

The analyses of this study do not imply the epistemological and ontological assumptions of the Schelerian theory. We do not maintain that emotions are a source of knowledge or that there is some objective hierarchy of values. Neither do we deny these assumptions. The study does not need to solve such epistemological and ontological issues because it is descriptive and analytical.

Consequently, in this study, the term 'value' has a subjective meaning. It denotes the aims of decisions and intentional objects of emotions. For example, if a player intends to win a game or emotionally appreciates the victory, it is a value in his/her perception. This is a terminological option that does not deny that some values may be 'objective' in some sense.

We assume that agents make value preferences which constitute some hierarchy of values. People can change their hierarchy of values, but at the moment of decision-making, they have some hierarchy. As Max Weber (1985, p. 565) maintains, at the top of this hierarchy are intrinsic values, which the agent considers the most precious. Emotions represent these values by the experience of unconditional ${ }^{1}$ duty to respect and implement them. They differ from instrumental values, which are precious only because they are a means (tool) to achieve some other (intrinsic or instrumental) value. Agents hierarchize instrumental values in accordance with their conditional relations to intrinsic values and to each other. Emotions represent instrumental values by the hypothetical imperative of respecting them because of their utility (Copp \& Zimmerman, 1985; Schroeder, 2012).

In this work, the term 'game' has a broad meaning, denoting three aspects of the same phenomenon. In a systemic sense, 'game' means a system (a logically ordered set) of rules which define situations, goals of a decision, and the means to achieve those goals. In a functional sense,

1 'Unconditional' here means 'independent of the predicted consequences of following the values in question'. 
a game is acting (decisions, emotions, behaviours of players) accordant to these rules. In a situational sense, a game consists of events happening according to the rules. For example, the rules of chess are chess in the systemic sense; chess in the functional sense consists of acts of players who respect the rules, and chess game sessions are chess in the situational sense. Furthermore, a player is a person who acts according to the rules.

This study shows that the phenomenon of emotional immersion takes place not only in the situations studied within ludology (for example, in video games or narrative games). This investigation takes the perspective of 'life philosophy', which frames some situations of decision-making, life engagements and social processes as games (Dixit, 1991; Fink, 1960a; Goffman, 1959, 1963; Jacko 2009, 2013; 2016; Järvinen, 2003; Juul 2005; Pfeffer, Salancik 1974, 1978; Sigmund, 1993). Consequently, in this study the idea of immersion is broad. We take into account the emotional immersion in life situations and fun.

\section{The emotional illusion}

Playing a game requires a limitation of perception, which deepens the perspective: we divert our attention from the reality that does not belong to the game and from our life-commitments to focus on the game. In this case, emotions follow the attention of the agent. They are not about any reality external to the game. They are not related to the life commitments of the player. These emotions are about the game and his/her participation in the game. This experience is typical for gameplay and fun. A similar experience appears in the perception of the works of art when people relish it, or in life situations when people focus their full attention on a particular task or event. For example, when someone acts in a dangerous situation, he/she can emotionally distance him-/herself from the fear of risks to focus his/her attention on the tasks and their performance. Such experience can also take place in life situations when people rest from daily commitments and appreciate the value of "little things'.

The above experience generates the emotional illusion of games. It occurs when the player emotionally experiences aims, rules, and his/her 
participation or success in the game as worthy (valuable) regardless of his/her hierarchy of values (King, n.d.; Shelley, 2013). An example situation is when someone does not consider winning the game as something important, but during the game his/her emotions make him/her engage in the game as if it was something significant.

In this experience, the player emotionally distances him/herself from his/her attachments to values that do not belong to the game. This distance allows players to 'break away' from 'ordinary life' and relish the game without being distracted by expectations about the consequences of the game. The distance creates a comfort zone, which is constitutive for aesthetic perception, fun, entertainment, and similar phenomena. ${ }^{2}$

The emotional illusion of games deforms the emotional 'picture' of values because in this experience emotions present some benefits in a game as more important than they are for the agent. However, this illusion is not misleading when it does not provoke the player to deny his/her life commitments. The experience of emotional illusion does not induce the player to ignore reality, such as the circumstances and consequences of the game. His/her attention does not focus on them, but he/she does not ignore them. For example, a teacher during a lecture can experience the illusion of games when he/she focuses his/her whole attention on the educational process. However, he/she can remain emotionally sensitive to the circumstances of the process and will stop the lecture in the case of a fire-alarm.

\section{The case of fun}

The experience of fun exemplifies the emotional illusion of games. In fun, players take an aesthetic distance to the reality - they focus their attention on their experience and its meaning. This distance is the source of aesthetic delight, which is a pleasure of contemplating sensual and emotional qualities and appreciating them for themselves - not for their

2 The concept of aesthetic distance originally appears in theories of aesthetic perception (Bullough, 1912/1989; Hilgers, 2016; Kant, 2007; King, n.d.; Kreitman, 2006; Shelley, 2013; Stolnitz, 1961). This distance can take place in the experience of playing games (Feezell, 2004; Huhtamo, 2005; King, n.d.). 
utility (Bullough, 1912; Feezell, 2004; Hilgers, 2016; Huhtamo, 2005; Kant, 2007; King, n.d.; Kreitman, 2006; Shelley, 2013; Stolnitz, 1961).

Because of the aesthetic distance to reality, players focus their attention on the fiction of the game they play. This fiction is the purely intentional product of their acts of playing the game. Emotions of fun are about this fiction - they are immediate experiences of aesthetic values that belong to it. They are aesthetic because the agent is aware of their fictional nature and his/her emotions reflect it.

The emotional illusion of games does not make players emotionally insensitive to values, which are external to the game. In this experience emotions about these values are 'dormant'. They do not interfere with fun without necessity. They 'wake up' only when the player notices that his/her participation in the game contradicts his/her hierarchy of values.

One should distinguish aesthetic distance to reality from ethical distance to the game. In the aesthetic distance, the player does not focus his/her attention on values, which are external to the game he/she is playing. In the ethical distance to the game, the player remains emotionally sensitive to these values, because his/her emotions reflect the fact that the game is a fiction. In the emotional ilusion of games, the player maintains emotional distance to reality without losing the ethical distance to the game.

\section{The emotional delusion}

The emotional illusion in games may turn into a delusion of games. It takes place when the emotions of the player motivate him/her to deny his/her hierarchy of values. In this delusion players emotionally experience their life as part of a game. Such emotions can distort the player's sense of his/her self-identity. For in this delusion he/she emotionally perceives him-/herself and his/her actions through the mechanics of the game, discerning that his/her self-identity is not reducible to their role in the game.

Due to the intentional structure of emotions in the delusion of games, one can distinguish its three types: practical, ethical and aesthetic delusion. (1) By 'pragmatic delusion' we mean situations when the player 
takes the practical attitude in games, which require aesthetic distance. (2) 'Ethical delusion' refers to cases where agents lose their ethical distance to a game. (3) By 'aesthetic delusion' we mean situations where agents take the aesthetic attitude in situations which require practical attitude and responsibility.

In the pragmatic delusion, players take the fiction of a game seriously. Their emotions react to this fiction as if it were something real. In consequence, players can emotionally experience a duty to sacrifice some of their life goals for their success in this game. This duty is misleading when it contradicts the hierarchy of values adopted by the player.

The attitude of powergaming is an example of this delusion. In this attitude, the player 'transfers' the game economy (rules of the game) to life situations. His/her involvement in the game directs his/her choices outside the game. For example, the game consumes his/her time devoted to other activities, and it absorbs his/her attention also after it ends (Taylor, 2003). In this case, the player's commitment to the game may become remarkable in his/her behaviour that does not belong to the game. For example, "How do you know that someone is a Power Gamer? Bloody, dark circles under their eyes, nervous tics and monotonous talks about the same game" ("Co znaczy pg?", 2015; the author's translation). The practical delusion of powergaming distorts fun: The player strives for success in the game in such a way that he/she stops enjoying the game (Taylor, 2003).

The ethical delusion occurs in life situations when agents strive for success in some game in a way which destroys their success in a more important game. In this case, their emotions provoke them to sacrifice more important values to achieve less important ones. Pragmatic economism is an example of this delusion. It consists in striving for some (for example, financial) profit in a way that threatens or contradicts the implementation of values considered by the individual/entity to be more valuable than this gain. In this attitude, people can treat market and economic rules as defining their life commitments. In effect of the pragmatic economism, people can invest life energy in the financial profit or career so much that they stop enjoying life.

Pragmatic economism can reflect in the theory of economism, which implies that humans only have the so-called material needs (food, shelter, and so forth) and that satisfying them entails satisfying all other 
needs and makes people happy by necessity (Bocheński, 1987). As Józef M. Bocheński remarks, economism is superstition because it is not consistent with experience, which "is visible even in rich countries, where material needs are satisfied with excess, but where many people, especially young people, feel unhappy and suffer" (Bocheński, 1987, p. 35, the author's translation).

The aesthetic delusion occurs when the agent takes the aesthetic attitude in situations which require a practical attitude and responsibility. In consequence of this delusion, his/her emotions can become 'blind' to non-aesthetic values. For example, someone plays a strategic online game that requires much time; at the same time, he/she has an exam to take, which is also time-consuming. In this situation, success in both games (the exam and the online game) is not possible: lack of time requires choosing between the online game and studying for the exam. The player knows this and values success in the exam above the success in the game. However, if he/she experiences the aesthetic delusion, his/her emotions may not reflect the conflict between the game and the exam. They can provoke him/her to wishfully believe that there is no such conflict or to avoid thinking about it. He/she may still want to pass the exam, but his/her emotions motivate him/her to sacrifice the chances to pass the exam for the fun of playing the online game.

Emotions of the aesthetic delusion may become insensitive to intrinsic values. For example, when people mob someone for fun, they may not emotionally experience that they humiliate and harm this person if they take the aesthetic attitude in this situation, even while believing that human well-being and dignity is an intrinsic value. Some cases of gamification may lead to the aesthetic delusion of emotions. For example, a soldier who remotely controls a battle drone can esthetically enjoy a combat game and not perceive emotionally that he/she kills people when he/she takes the aesthetic attitude in the game.

Søren Kierkegaard in his books Fear and Trembling and Either/Or carries out a phenomenological analysis of the aesthetic delusion. He calls it the "aesthetic stage of existence". As Kierkegaard notes, this attitude is typical of children, who have a natural tendency to ignore the consequences of their play. In consequence, it may pose a threat to them or other people. The mental maturity of people relies, among other things, 
on the fact that they can play games in a way that does not compromise their hierarchy of values and responsibility (McDonald, 2017).

\section{The principle of a rational player}

According to Weber, rational decisions are instrumentally rational and value-rational. In the former, an individual chooses the means which (according to his/her knowledge) are effective in achieving the goal of the decision. Value-rational decisions are consistent with the hierarchy of values adopted by the agent. Value-irrational decisions may be instrumentally rational, but they are not entirely rational since they contradict the agent's hierarchy of values. A rational person does not sacrifice the benefits he/she considers more critical in order to achieve ones that are less significant according to his/her hierarchy of values. The value-rational attitude is the inclination to make value-rational decisions. Value-irrational agents do not have this attitude (Weber, 1985, p. 565).

The above conception of rational actions is compatible with some systemic theories of games, like the mathematical theory of games, which show that the player can simultaneously participate in more than one game (in the systemic sense), where a higher evaluated game determines and overrides the success and sense of actions in a lower regarded subgame. A rational player does not abandon the success of the superior game for the sake of success in an inferior game (Dixit, 1991; Fink, 1960; Jacko 2009, p. 119; Järvinen, 2003; Juul 2005; Pfeffer, Salancik 1974, 1978; Taylor, 2003, p. 306).

As this study shows, the emotional delusion of games is conductive to instrumentally irrational and value-irrational decisions and attitudes. The reason is that emotions of this delusion motivate agents to abandon their victory in superior games to win in a less important game. For example, as noted by Taylor (2003, p. 302-303), choices in powergaming are instrumentally rational only in a single game, but they are not instrumentally rational beyond this game since they are not efficient in attaining the aims which do not belong to the game. Such choices are value-irrational. If, for instance, the player values social relations more than victory in the game, he/she should promote their quality, but in the 
case of powergaming he/she does not - he/she can sacrifice these values for the victory in a game (Taylor 2003, p. 302-303).

Similarly, the ethical delusion of emotions is conducive to value-irrational decisions and attitudes. For example, people who take the attitude of practical economism may be instrumentally rational in attaining particular economic goods. However, they are not value-rational when they satisfy their economic needs at the expense of their happiness or other intrinsic values.

\section{Conclusion: The normative aspect of emotional immersion}

The objectives of the study are descriptive and analytical. Therefore, it does not offer any answer to normative questions, such as: Should players take the value-rational attitude in games? or Why should players be valuerational? The affirmative answer to the former question is an assumption of Weber's theory of rational attitudes and is implicit in some theories of ludology, for example, in the principle of fair play in sport or computer games (D'Agostino, 1995; Feezell, 2004; Floridi, 1999, 2003, 2005; Sicart, 2005). These theories also indicate some answers to the latter question. They show that value-irrational decisions are dangerous and socially harmful (D’Agostino, 1995; Consalvo, 2005; Dodig-Crnkovic, Larsson, 2005; Feezell, 2004; Järvinen, 2003; McCormick, 2001; Novak, Coakley 2013; Reynolds, 2002). One can find some answers to these questions in the philosophical theories which show that value-irrational decisions contradict the freedom of decision-makers (Sartre, 1943; Fromm, 1941), deny their self-identity (D’Agostino, 1995; Consalvo, 2005; Dodig-Crnkovic, Larsson, 2005; Feezell, 2004; Järvinen, 2003; Kand 2010; McCormick, 2001; Novak, Coakley 2013; Reynolds, 2002), and corrupt the experience of fun in fun-games (Jacko, 2015, p. 58-59). However, these theories do not directly regard the emotional immersion of games. Constructing a moral theory of immersion can be the task for further examination, which can take the point of departure in the analyses of this study. 


\section{Literature}

Anderson, C, A., Dill, K. E. (2000). Video games and aggressive thoughts, feelings and behavior in the laboratory and in life. Journal of Personality and Social Psychology, 78(4), 772-790.

Baños, R., Botella, C., Alcañiz, M., Liaño, V., Guerrero, B., Rey, B. (2004). Immersion and emotion: Their impact on the sense of presence. CyberPsychology \& Behavior, 7, 734-741.

Bocheński, J. M. (1987). Sto zabobonów: krótki filozoficzny stownik zabobonów. Paryż: Instytut Literacki.

Brown, E., Cairns, P. (2004) A grounded investigation of game immersion. CHI 2004. Vienna, 1297-1300.

Bullough, E. (1912). "Psychical distance" as a factor in art and as an aesthetic principle. British Journal of Psychology, 5, 87-117.

Bushman, B. J., Anderson, C. A. (2002). Violent video games and hostile expectations: A test of the General Aggression Model. Personality and Social Psychology Bulletin, 28(12), 1679-1686.

Consalvo, M. (2005). Rule sets, cheating, and magic circles: Studying games and ethics. International Review of Information Ethics, 4, 7-12.

Co to znaczy pg? Power Gaming. (2015). Retrieved 3 December 2017 from <http://co-to-znaczy.pl/co-to-znaczy-pg-power-gaming/>.

Cowley, B., Charles, D., Black, M., Hickey, R. (2008). Toward an understanding of flow in video games. Computers in Entertainment, 6(2), 1-27.

Csíkszentmihályi, M. (1975). Beyond Boredom and Anxiety. San Francisco: Jossey-Bass Publishers.

Csikszentmihalyi, M. (1990). Flow: The Psychology of Optimal Experience. New York: Harper Perennial.

D'Agostino, F. (1995). The ethos of games. In J. Morgan, K. V. Meier (Eds.), Philosophic Enquiry in Sport (pp. 42-49). Champaign, IL: Human Kinetics. Dansky, R. 2006. Introduction to game narrative. In C. Bateman (Ed), Game Writing: Narrative Skills for Videogames (p. 1-23), Boston, Massachusetts; Charles River Media.

Davis, Z., Steinbock, A. (2016). Max Scheler. In E. N. Zalta (Ed.), The Stanford Encyclopedia of Philosophy (Fall 2016). Metaphysics Research Lab, Stanford University. Retrieved from $<$ https://plato.stanford.edu/archives/fall2016/entries/scheler/>. 
Dixit, A., Nalebuff, B. (1991). Thinking Strategically. New York: Norton.

Dodig-Crnkovic, G., Larsson, T. (2005). Game ethics: Homo ludens as computer game designer and consumer. International Review of Information Ethics, 4, 19-23.

Feezell, R. M. (2004). Sport, Play, and Ethical Reflection. Urbana, Chicago: University of Illinois Press.

Fink, E. (1960). The ontology of play. Philosophy Today, 4(2), 95-109.

Floridi, Luciano. (1999). Information ethics: On the philosophical foundation of computer ethics. Ethics and Information Technology, 1, 37-56.

Floridi L. (2003). On the intrinsic value of information objects and the infosphere. Ethics and Information Technology, 4(4), 287-304.

Floridi, L. (2005). The ontological interpretation of informational privacy. Ethics and Information Technology, 7(4), 185-200.

Fromm, E. (1941). Escape from Freedom. New York: Henry Holt and Company, LLC.

Goffman E. (1959) The Presentation of Self in Everyday Life. Garden City, New York: Doubleday Anchor.

Goffman E. (1963) Behavior in Public Places. New York: Glencoe, IL: Free Press.

Grüsser, S. M., Thalemann, R., Griffiths, M. D. (2007). Excessive computer game playing: Evidence for addiction and aggression? CyberPsychology E Behavior, 10(2), 290-292.

Hilgers, T. (2016). Aesthetic Disinterestedness: Art, Experience, and the Self. New York, London: Routledge.

Hochschild, A. R. (1979). Emotion work, feeling rules, and social structure. The American Journal of Sociology, 85(3), 551-575.

Huhtamo, E. (2005). Slots of fun, slots of trouble. An archaeology of arcade gaming. In J. Goldstein, R. Joost (Eds.), Handbook of Computer Games Studies (pp. 1-5). Cambridge: The MIT Press.

Jacko, J. F. (2009). Ontologia myślenia strategicznego. Homo Ludens, 1(1), 113-121.

Jacko, J. F. (2013) . „Czym jest gra?”. Uwagi o analogicznej wieloznaczności pojęcia gry. Kontekst nauk o zarządzaniu. Homo Ludens, 5(1), 92-107. Jacko, J. F. (2015) Wewnętrzna etyka gry. Homo Ludens, 7(1), 49-64. Jacko, J. F. (2016) Czym jest gra? Uwagi o przedmiocie ludologii. Analiza fenomenologiczno-metodologiczna. Homo Ludens, 9(1), 65-83. 
Järvinen, A. (2003). The elements of simulation in digital games: System, representation and Interface. Dichtung-Digital, 4. Retrieved 19 December 2017 from <http://www.dichtung-digital.de/2003/4-jaervinen.htm>. Jennett, C., Cox, A. L., Cairns, P., Dhoparee, S., Epps, A., Tijs, T., Walton, A. (2008). Measuring and defining the experience of immersion in games. International Journal of Human-Computer Studies, 66(9), 641-661. Juul, J. (2005). Half-Real: Video Games between Real Rules and Fictional Worlds. Cambridge: MIT Press.

Kant, I. (2007). Critique of Judgment (J. Bernard, Trans.). New York: Cosimo, Inc.

King, A. (n.d.). Aesthetic attitude. Internet Encyclopedia of Philosophy. Retrieved 19 December 2017 from <http://www.iep.utm.edu/aesth-at/\#SH1a>.

Komulainen, J., Takatalo, J., Lehtonen, M., Göte, M. (2008). Psychologically structured approach to user experience in games. Proceedings of the 5 th NordiCHI, Lund.

Kreitman, N. (2006). The varieties of aesthetic disinterestedness. Contemporary Aesthetics. Retrieved 19 December 2017, from <http://www. contempaesthetics.org/newvolume/pages/article.php?articleID=390>.

Lindley, C. A., Nacke, L., Sennersten, C. C. (2008). Dissecting play: Investigating the cognitive and emotional motivations and effects of computer gameplay. CGAMESo8, Proceedings of the 13th International Conference on Computer Games: AI, Animation, Mobile, Interactive Multimedia, Educational \& Serious Games, Wolverhampton.

Mandryk, R. L., Inkpen, K. M. (2004). Physiological indicators for the evaluation of co-located collaborative play. Proceedings of the ACM Conference on Computer Supported Cooperative Work. CSCW, Chicago. Retrieved 21 December 2017 from <https://www.researchgate.net/ publication/220879431_Physiological_indicators_for_the_evaluation_ of_co-located_collaborative_play>.

Mathiak, K., Weber, R. (2006). Toward brain correlates of natural behavior: MRI during violent video games. Human Brain Mapping, 27(12), 948-956.

McCormick, M. (2001). Is it wrong to play violent video games? Ethics and Information Technology, 3, 277-287.

McDonald, W. (2017). Søren Kierkegaard. In E. N. Zalta (Ed.), The Stanford Encyclopedia of Philosophy (Winter 2017). Metaphysics Research Lab, 
Stanford University. Retrieved 19 December 2017 from <https://plato. stanford.edu/archives/win2017/entries/kierkegaard/>.

Nacke, L. E., Drachen, A., Kuikkaniemi, K., Niesenhaus, J., Korhonen, H. J., Hoogen, W. M., Kort, Y. (2009). Playability and player experience research. Proceedings of DiGRA 2009: Breaking New Ground: Innovation in Games, Play, Practice and Theory, London.

Nacke, L., Lindley, C. (2009). Affective ludology, flow and immersion in a first-person shooter: Measurement of player experience. Loading..., 3(2). Retrieved 19 December 2017, from <http://journals.sfu.ca/loading/ index.php/loading/article/view/72>.

Ortony, A., Clore, L., Collins, A. (1990). The Cognitive Structure of Emotions. Cambridge: Cambridge University Press.

Pfeffer, J., Salancik, G. R. (1978). The External Control of Organization: A Resource Dependence Perspective. New York: Harper \& Row.

Qin, H., Rau, P. L. P., Salvendy, G. (2009). Measuring player immersion in the computer game narrative. International Journal of Human-Computer Interaction, 25(2), 107-133.

Qin, H., Rau, P. L. P., Salvendy, G. (2010). Effects of different scenarios of game difficulty on player immersion. Interacting with Computers, $22(3), 230-239$.

Ravaja, N., Turpeinen, M., Saari, T., Puttonen, S., Keltikangas-Järvinen, L. (2008). The psychophysiology of James Bond: Phasic emotional responses to violent video game events. Emotion, 8(1), 114-120.

Ravaja, N., Saari, T., Laarni, J., Kallinen, K., Salminen, M., Holopainen, J., (2005). The psychophysiology of video gaming: Phasic emotional responses to game events. Proceedings of 2005 DiGRA Conference: Changing Views - Worlds in Play, Burnaby.

Ravaja, N., Saari, T., Salminen, N., Laarni, J., Kallinen K. (2009). Phasic emotional reactions to video game events: A psychophysiological investigation. Media Psychology, 12(4), 343-367.

Reynolds, R. (2002). Playing a "good" game: A philosophical approach to understanding the morality of games. Retrieved 19 December 2017 from: <http://www.igda.org/articles/rreynolds_ethics.php>.

Sartre, J. P. (1943). L'Être et le Néant. Essai d’ontologie phénoménologique. Paris: Gallimard. 
Shelley, J. (2013). The concept of the aesthetic. In E. N. Zalta (Ed.), The Stanford Encyclopedia of Philosophy (Fall 2013). Retrieved 19 December 2017 from <http://plato.stanford.edu/archives/fall2013/entries/ aesthetic-concept/>.

Sicart, M. (2005). Game, player, ethics: A virtue ethics approach to computer games. International Review of Information Ethics, 4(12), 46-52.

Sicart, M. (2009). The Ethics of Computer Games. Cambridge, London: The MIT Press.

Sigmund K. (1993) Games of Life. Oxford: Oxford University Press.

Slater, M. (2002). Presence and the sixth sense. Presence: Teleoperators and Virtual Environments, 11(4), 435-439.

Stolnitz, J. (1961). On the origins of 'aesthetic disinterestedness'. The Journal of Aesthetics and Art Criticism, 20, 131-143.

Sweetser, P., \& Wyeth, P. (2005). Game flow: a model for evaluating player enjoyment in games. Computers in Entertainment (CIE), 3(3), 3.

Takatalo, J., Häkkinen, J., Kaistinen, J., \& Nyman, G. (2010). Presence, involvement, and flow in digital games. In R. Bernhaupt (Ed). Evaluating User Experience in Games (pp. 23-46). London: Springer.

Taylor, T. L. (2003) Power gamers just want to have fun?: Instrumental play in a MMOG. In Proceedings of the 1st Digra conference: Level Up. The University of Utrecht. Digital Games Research Association (pp. 300-311). Utrecht.

Weber, M. (1985) Gesammelte Aufsätze zur Wissenschaftslehre. Tübingen: Hrsg. von Johannes Winckelmann.

Zhang, C., Perkis, A., \& Arndt, S. (2017). Spatial immersion versus emotional immersion, which is more immersive? Presented at the Conference: 9th International Conference on Quality of Multimedia Experience, Erfurt. Retrieved from < https://www.researchgate.net/ publication/317357598_Spatial_Immersion_versus_Emotional_Immersion_Which_is_More_Immersive>. 
Jan F. Jacko, PhD, Hab. - Proffesor at Jagiellonian University in Kraków

\section{Doświadczenie wartości w przeżyciu emocjonalnej imersji}

Abstrakt: W pracy przedstawiono fenomenologiczną analizę doświadczenia wartości w przeżyciu emocjonalnej imersji w grach. Tekst pokazuje dwa jego warianty: emocjonalną iluzję oraz emocjonalne kłamstwo. W emocjonalnej iluzji gracz emocjonalnie dystansuje się względem własnej hierarchii wartości, aby rozkoszować się grą. W emocjonalnym kłamstwie emocje motywują graczy do decyzji niezgodnych z przyjętą przez nich hierarchią wartości. Zaproponowano wyjaśnienie tych doświadczeń w kontekście niektórych teorii racjonalnego działania.

Stowa kluczowe: immersja, racjonalny gracz, etyka, zarządzanie wrażeniami 